УДК 346.2:336.761(477)

DOI https://doi.org/10.32844/2618-1258.2019.5-2.26

КУЗНСЦОВА Є.А.

\title{
ГЕНЕЗА ПРАВОВОЇ РЕГЛАМЕНТАЦІЇ ФІНАНСОВО-ПРАВОВОГО РЕГУЛЮВАННЯ ДІЯЛЬНОСТІ ПРОФЕСІЙНИХ УЧАСНИКІВ РИНКУ ЦІННИХ ПАПЕРІВ
}

\begin{abstract}
У статті розглянуті основні соціально-економічні, правові та інші передумови та фактори, що зумовили історичні особливості формування та розвитку професійних учасників ринку цінних паперів в Україні починаючи з 1990 року і до сьогодення.

Визначено основні етапи становлення професійних учасників ринку цінних паперів і характерні особливості кожного з них, зокрема: 1) 1990-1994 pp. - період виходу України зі складу Радянського Союзу, що збігся в часі з процесом створення приватних акціонерних та фінансових компаній, які займалися залученням коштів населення під випуск власних цінних паперів; 2) 1995-1999 pp. - етап, що розпочався 3 випуском в обіг та створенням вторинного ринку купівлі-продажу компенсаційних сертифікатів (КС) i чорного ринку приватизаційних майнових сертифікатів (ПМС) - ваучерів; 3) 2000-2008 рр. - період, що характеризувався пошуком ефективного власника, що зумовило продаж підприємств великої приватизації, створення галузі професійних учасників РЦП та активне входження до українського фондового ринку зовнішнього капіталу; 4) з 2009 р. й дотепер - етап, що $€$ незмінним унаслідок завершення перерозподілу власності шляхом концентрації контрольних і блокуючих пакетів акцій.

3 історичного погляду проаналізовані основні тенденції, напрями, особливості та проблеми розвитку професійних учасників ринку цінних паперів в Україні. Розглянуті основні проблеми державного регулювання фондового ринку й формування його нормативно-правової бази в перехідний період.

Розглянуто передумови прийняття нової редакції Закону України «Про цінні папери та фондовий ринок», наведено його порівняльну характеристику із попереднім Законом України «Про цінні папери і фондову біржу». Зазначено сучасні тенденції розвитку РЦП, а також переваги, які має нова редакція Закону. Проаналізовано, яким чином законодавчі зміни впливатимуть на подальший розвиток РЦП і економіки України.
\end{abstract}

Ключові слова: иінні папери, ринок иінних паперів, фондовий ринок, біржа цінних паперів, позабіржова фондова торговельна система, державна комісія з ијнних паперів та фондового ринку, професійні учасники ринку циінних паперів.

The article deals with the main socio-economic, legal and other prerequisites and factors that have caused the historical peculiarities of the formation and development of professional participants in the securities market in Ukraine since 1990 and up to the present.

The main stages of formation of professional participants of the securities market are determined and the characteristic features of each of them, namely: 1) 1990-1994 - the period of Ukraine's withdrawal from the Soviet Union, which coincided with the process of creation of private joint-stock and financial companies engaged in raising funds of the population for the issue of their own securities; 2) 1995-1999 - began with the launch and creation of a secondary market for the sale and purchase of compensation certificates (CUs) and the black market for privatization property certificates (ICPs) - vouchers; 3) 2000-2008 - was characterized by the search for an effective owner, which led to the sale of large-scale privatization enterprises, the creation of an industry of professional participants of the RCP and the active entry into the Ukrainian stock market of foreign

(C) КУЗНСЦОВА Є.А. - здобувач наукового ступеня доктора філософії (кандидата наук) кафедри фінансового права та фіскального адміністрування (Національна академія внутрішніх справ) 
capital; 4) from 2009 until now - is unchanged due to the completion, mainly, of the redistribution of property by concentration of controlling and blocking blocks of shares.

From a historical point of view, the main tendencies, directions, features and problems of development of professional participants of the securities market in Ukraine have been analyzed. The main problems of state regulation of the stock market and the formation of its regulatory framework in the transition period are considered.

The prerequisites for the adoption of a new wording of the Law of Ukraine "On Securities and the Stock Market" are considered, and its comparative characteristics with the previous Law of Ukraine "On Securities and Stock Exchange" are given. The current trends in the development of the RCP are outlined, as well as the advantages of the new version of the Law. It is analyzed how the legislative changes will influence the further development of the RCS and the economy of Ukraine.

Key words: securities, Securities Market, Stock Market, stock exchange, OTC stock trading system, State Commission on Securities and Stock Market, professional participants in the securities market.

Вступ. Починаючи безпосереднє висвітлення проблеми, зауважимо, що в СРСР не існувало РЦП, а перший прототип акцій з'явився тільки після прийняття Радою Міністрів СРСР постанови від 15 жовтня 1988 р. № 1195 «Про випуск підприємствами й організаціями цінних паперів». Ініціатором перших акцій трудового колективу в Україні було Львівське ВО «Електрон». Незважаючи на те, що експеримент виявився безперспективним, а цінні папери, випущені згідно із цією постановою, справедливо критикувалися, їхня поява була першим кроком у напряму створення ринку цінних паперів в Україні. На 01 липня 1991 року тільки в реєстр Міністерства фінансів СРСР було внесено вже більше 240 акціонерних товариств із загальною сумою статутного фонду 19,4 млрд карбованців [1, с. 3]. Але треба зазначити, що правова характеристика акцій у законодавстві СРСР не була чітко визначена, і це було зумовлено як суб'єктивними, так і об'єктивними причинами.

Постановка завдання. Метою статті $\epsilon$ - проаналізувати з історичного погляду фінансово-правові, соціально-економічні, політичні та інші фактори, що впливали на процес формування та розвитку професійних учасників ринку цінних паперів в Україні в умовах глибокої економічної кризи, відродження національної державності та опору ринковим реформам з боку певних сил в українському суспільстві.

Результати дослідження. Розглянемо історичні умови виникнення та проблеми розвитку професійних учасників РЦП в Україні, починаючи з перехідного періоду і до сьогодення за такими етапами.

Перший етап (1990-1994 рр.) можна назвати першими кроками РЦП в Україні. До групи законодавчих актів першого покоління, якими почали регулюватися відносини на українському фондовому ринку, передусім треба віднести Закони України «Про власність», «Про цінні папери i фондову біржу», «Про господарські товариства», «Про заставу», «Про приватизаційні папери», «Про банки і банківську діяльність» та інші. Але Закони України у сфері підприємницької діяльності, прийняті в 1991-1992 рр., за своєю структурою та змістом практично продублювали відповідні законодавчі акти СРСР. Безперечним досягненням вищезазначених законів було те, що в них уперше були закріплені положення про цінні папери як об'єкти права власності, про право суб'єктів підприємницької діяльності на випуск власних цінних паперів, про право банків на здійснення операцій із цінними паперами тощо.

Другий етап (1995-1999рр.) характеризувався значним зростанням фондового ринку України, каталізатором чого можна вважати два моменти: прискорення темпів приватизації та створення державної системи регулювання фондового ринку, зокрема Указом Президента України від 12 червня 1995 року було утворено Державну комісію з цінних паперів та фондового ринку (ДКЦПФР). Також запроваджується низка законодавчих ініціатив, зокрема, вступають в силу Закони України «Про державне регулювання ринку цінних паперів в Україні», «Про Національну депозитарну систему та особливості електронного обігу цінних паперів в Україні», на державному рівні ухвалюється «Концепція функціонування та розвитку ринку цінних паперів в Україні». Ще одна проблема, що спостерігалась у той час, - це безсистемність використання основних термінів у сфері професійної діяльності на РЦП України. Це мало місце через дві основні причини. Однією з них була недостатня обізнаність з ринковими механізмами, другою - законодав- 
че оформлення здійснюваних у країні соціально-економічних ринкових перетворень. До певної міри ці причини взаємозалежні, а їхні наслідки взаємозумовлені [2, с. 4].

Третій етап розвитку ринку цінних паперів в Україні (2000-2008 рр.) характеризувався пошуком ефективного власника, що зумовило продаж підприємств великої приватизації, створення галузі професійних учасників РЦП та активне входження до українського фондового ринку зовнішнього капіталу. На третьому етапі тривали заходи законодавчого та нормативно-правового регулювання розвитку ринку цінних паперів. На той час в Україні вже існувало більше 100 законодавчо-нормативних актів, які стосувалися різних сторін регулювання правовідносин на українському фондовому ринку.

У 2001-2005 рр. організований РЦП в Україні був представлений уже 7 фондовими біржами та 2 торговельно-інформаційними системами. Фондові біржі функціонували на території України у вигляді акціонерних товариств. Вони зосереджували попит і пропозицію цінних паперів, сприяли формуванню їхнього ринкового курсу й здійснювали свою діяльність відповідно до чинного законодавства України, статутів і правил біржової торгівлі [3, с. 117].

Найважливішим моментом цього етапу необхідно відзначити прийняття Верховною Радою України Закону України «Про цінні папери та фондовий ринок» (реєстраційний № 7818) від 23 лютого 2006 року. Иого прийняття, як наголошували парламентарі, давно назріло, оскільки попередній Закон, ухвалений у 1991 році, застарів. Загалом новий законодавчий акт передбачав приведення норм, що регулюють питання цінних паперів і фондового ринку, у відповідність до норм європейського законодавства та положення Цивільного й Господарського кодексів України. А також він враховує сучасні тенденції розвитку фондового ринку, зокрема появу нових видів цінних паперів та нових видів діяльності.

Четвертий етап розвитку ринку цінних паперів в Україні (2009 р. - сьогодення) є незмінним внаслідок завершення перерозподілу власності шляхом концентрації контрольних і блокуючих пакетів акцій. Наступним кроком у регулюванні ринку цінних паперів України став Указ Президента України про створення Національної комісії з цінних паперів та фондового ринку України (НКЦПФРУ) № 1063/2011 від 23.11.2011 року.

На цьому етапі структура ринку акцій представлена значною кількістю професійних учасників РЦП. Станом на 31.12.2011 р. НКЦПФРУ було видано 1679 ліцензій професійним учасникам фондового ринку на провадження професійної діяльності, що є меншим, ніж у 2010 році (1 807 ліцензій) у зв'язку з приведенням діяльності професійних учасників до вимог Закону України «Про внесення змін до деяких законодавчих актів України щодо підвищення вимог до статутного капіталу професійних учасників фондового ринку», прийнятому у 2010 році.

За 2013-2018 роки в Україні спостерігається зменшення обсягів капіталізації, яке значною мірою пов'язане із зменшенням кількості випусків акцій, внесених до біржового реєстру як таких, що відповідають вимогам лістингу [4, с. 22]. Ця тенденція негативно впливає на рівень розвитку фондового ринку загалом. За даними Національної комісії з цінних паперів та фондового ринку (НКЦПФР), у 2018 році, порівняно з 2017 роком, темп приросту обсягів торгів на ринку цінних паперів становив 26\% за зростання ВВП на $3,2 \%$. Співвідношення обсягів торгів на ринку цінних паперів до ВВП - 19,8\%. За підсумками 2018 року спостерігалося зростання обсягу торгів на ринку цінних паперів, порівняно з 2017 роком, на 26\% - до 590,59 млрд грн.

Хоча порівняно з 2017 роком обсяг торгів збільшився, але, порівнюючи з 2016 роком, цей показник зменшився майже у 4 рази. Частково це скорочення можна пояснити неврахуванням у 2017 року. Проте таке зменшення обсягів торгів можна також пов'язати із впровадженням ряду законодавчих актів, спрямованих на удосконалення регулювання та впровадження прозорості на ринку цінних паперів, таким чином відсіявши деяких недобросовісних учасників фондового ринку [5, с. 130].

За результатами торгів на організованому ринку протягом січня-серпня 2019 року обсяг біржових контрактів з цінними паперами склав 205,75 млрд грн. Протягом січня-серпня 2019 року, порівняно з даними аналогічного періоду 2018 року, обсяг біржових контрактів з цінними паперами на організаторах торгівлі збільшився на 17,63\% (січень-серпень 2018 року - 175 млрд. грн.) $[6$, c. 19]. Незважаючи на різницю у стані українського біржового ринку порівняно із іншими біржами світу, все ж таки існують позитивні тенденції його подальшого розвитку та ряд проблем, без вирішення яких неможливе успішне виконання фондовим ринком покладених на нього функцій: залучення інвестицій та розподілу капіталу.

На цей час законодавче регулювання РЦП забезпечує загальнообов'язковий регулюючий вплив на діяльність та поведінку всіх учасників РЦП. Надалі розглянемо нормативно-пра- 
вові акти, що регулюють відносини у частині створення і функціонування саме професійних учасників РЦП:

- основним нормативно-правовим актом у системі загального законодавства $є$ Конституція України від 28 червня 1996 року. В ст. 92 Конституції України проголошується, що винятково законами України встановлюються засади створення і функціонування фінансового, грошового, кредитного та інвестиційних ринків;

- правові основи господарської діяльності (господарювання), яка базується на різноманітності суб'єктів господарювання різних форм власності, встановлює Господарський кодекс України від 16 січня 2003 року. Предметом регулювання Господарського кодексу України є визначення основних засад господарювання в Україні та регулювання господарських відносин, що виникають у процесі організації, та здійснення господарської діяльності між суб'єктами господарювання, а також між цими суб'єктами та іншими учасниками відносин у сфері господарювання (ст. 1 ГК);

- цивільним законодавством регулюються особисті немайнові та майнові відносини (цивільні відносини), засновані на юридичній рівності, вільному волевиявленні, майновій самостійності їх учасників. Загальні засади регулювання відносин власності в Україні встановлюються Цивільним кодексом України від 16 січня 2003 року [6];

- Закон України «Про господарські товариства» від 19 вересня 1991 року визначає поняття і види господарських товариств, правила їх створення, діяльності, а також права і обов'язки їх учасників та засновників;

- Закон України «Про товариства з обмеженою та додатковою відповідальністю» від 06 лютого 2018 року визначає правовий статус товариств 3 обмеженою відповідальністю та товариств 3 додатковою відповідальністю, порядок їх створення, діяльності та припинення, права та обов'язки їх учасників;

- Закон України «Про акціонерні товариства» від 17 вересня 2008 року визначає порядок створення, діяльності, припинення, виділу акціонерних товариств, їх правовий статус, права та обов'язки акціонерів. Отже, кожний з професійних учасників РЦП може отримати ліцензію на відповідний вид професійної діяльності лише за умови, що є юридичною особою, створеною відповідно до норм вищевказаних законів.

- Закон України «Про ліцензування певних видів господарської діяльності» від 01 червня 2000 року визначає види господарської діяльності, які підлягають ліцензуванню, у тому числі професійну діяльність на РЦП (п. 3 ст. 7), яка ліцензується з урахуванням особливостей, визначених Законом України «Про державне регулювання ринку цінних паперів в Україні»; Порядок та умови видачі ліцензії на провадження окремих видів професійної діяльності на фондовому ринку (ринку цінних паперів) визначаються рішенням Національної комісії з цінних паперів та фондового ринку від 14.05.2013 № 817;

- Закон України «Про фінансові послуги та державне регулювання ринків фінансових послуг» від 12 липня 2001 року встановлює загальні правові засади у сфері надання фінансових послуг, правове забезпечення діяльності та розвитку конкурентноспроможного ринку фінансових послуг. Цей Закон регулює відносини, що виникають між учасниками ринків фінансових послуг під час здійснення операцій з надання фінансових послуг. Ринок фінансових послуг співвідноситься з ринком цінних паперів як загальне та спеціальне поняття, оскільки включає не лише РЦП, а й ринки банківських послуг, страхових послуг, інвестиційних послуг та інші види ринків, що забезпечують обіг фінансових активів (п. 6 ст. 1 Закону);

- Закон України «Про запобігання та протидію легалізації (відмиванню) доходів, одержаних злочинним шляхом, фінансуванню тероризму та фінансуванню розповсюдження зброї масового знищення» від 14 жовтня 2014 року регулює відносини у сфері запобігання та протидії запровадженню в легальний обіг доходів, одержаних злочинним шляхом, з цією метою запроваджується система первинного фінансового моніторингу, серед суб'єктів якого виділяються професійні учасники РЦП.

Поряд із зазначеними нормативно-правовими актами необхідно звернути увагу на окрему групу актів, які складають законодавство про професійну діяльність на РЦП. Суспільні відносини, які виникають в процесі створення професійних учасників РЦП, ліцензування та здійснення ними діяльності на РЦП, є предметом законодавства про професійну діяльність на РЦП. Тому законодавство про професійну діяльність на РЦП утворюють нормативно-правові акти, які регламентують загальні засади функціонування професійних учасників РЦП, зокрема, порядок створення професійних учасників РЦП, управління, припинення та умови здійснення професійної діяльності на РЦП, а також визначають права та обов'язки професійних учасників РЦП. 
Отже, законодавство про професійну діяльність на РЦП - система нормативно-правових актів, що регулюють відносини у сфері створення професійних учасників РЦП, ліцензування, провадження та припинення їх діяльності на РЦП. Аналіз нормативно-правових актів, що його складають, дозволяє зробити умовний поділ законодавства про професійну діяльність на загальне та спеціальне.

Висновки. Підсумовуючи вищесказане, можемо зробити певні висновки:

- по-перше, у 1991 році з’явилась об'єктивна необхідність прийняття Закону України «Про цінні папери та фондову біржу». Саме цей нормативно-правовий акт став відправною точкою у становленні і формуванні фондового ринку України. Адже він сприяв появі на ринку основних видів фінансових інструментів і інституційних учасників ринку цінних паперів;

- по-друге, створення ДКЦПФР та прийняття Закону України «Про державне регулювання ринку цінних паперів» стало наступним етапом у розвитку фондового ринку. 3'явились нові правила і методи державного регулювання, що привело діяльність учасників ринку цінних паперів і обіг фінансових інструментів у нормоване законодавче русло;

- по-третє, існування недоліків і непорозумінь на ринку цінних паперів призвело до появи нової редакції Закону України «Про цінні папери та фондовий ринок». Завдяки цьому законодавчому акту було приведено у відповідність нормативно-правову базу, зокрема положення Господарського і Цивільного законодавства. Крім того, поява нових видів цінних паперів, на нашу думку, повинна дати поштовх подальшому, більш активному розвитку РЦП;

- по-четверте, дослідження законодавства показало, що все ж таки правове регулювання потребує змін і удосконалення, враховуючи, що цей Закон обмежує обіг певних видів цінних паперів (насамперед інструментів грошового ринку) та певних учасників фондового ринку (йдеться про ТIC, оскільки в даному нормативно-правовому акті йдеться лише про надання права діяльності фондовим біржам). Адже виконання принципу розвитку фондового ринку, а саме рівного права доступу всіх його учасників, повинен бути забезпечений, на нашу думку, саме цим Законом. У кінцевому підсумку варто сказати, що Закон України «Про цінні папери і фондовий ринок» регулює відносини, що виникають під час розміщення, обігу цінних паперів і провадження професійної діяльності на фондовому ринку, з метою забезпечення відкритості та ефективності функціонування фондового ринку [8, с. 5]. Ми вважаємо, що головним завданням цього Закону має бути забезпечення фінансової безпеки держави, попередження можливих кризових явищ, створення умов для сталого і ефективного розвитку фондового ринку зокрема і економіки країни загалом.

\section{Список використаних джерел:}

1. Мозговий О., Лук'яненко Д. Ринок цінних паперів: регуляторна структуризація в умовах глобалізації. Ринок изіних паперів України. 2005. № 9. С. 3.

2. Новошинська Л., Стасюк Ф. Антологія українського ринку цінних паперів. Ринок цуінних паперів Украӥни. 2004. № 5. С. 3-16.

3. Кондрашихін А.Б. Фінансові аспекти відносин учасників ринку цінних паперів. Фінанси України. 2003. № 12. С. 117.

4. На фондовому ринку. Економіст. 2005. № 11. С. 22-23.

5. Шелудько В.М. Фінансовий ринок : навч. посібник. Київ : Знання-Прес, 2002. 535 с. (Вища освіта XXI ст.).

6. Назарчук М. О некоторых недостатках нового Закона Украины «Про цінні папери та фондовий ринок». Цінні папери Украӥни. 2006. № 37(429). 21 вересня. С. 19.

7. Сохацька O.M. Міжнародні ф'ючерсні ринки: теоретико-методологічні аспекти : монографія. Тернопіль : Карт-Бланш, 2002. 454 с.

8. Закон України «Про цінні папери та фондовий ринок» від 23 лютого 2006 р. № 3480-IV. Податки та бухгалтерський облік. 2006. № 35-36 (906-907). С. 527.

9. Закон України «Про цінні папери і фондову біржу» від 18 червня 1991р. № 1201-XII (відмінений в зв’язку з прийняттям нового закону). 